\title{
AleXANDER BuRnasov
}

Ural Federal University, Yekaterinburg, Russia

MARIA ILYUSHKINA

Ural Federal University, Yekaterinburg, Russia

YURY KOVALEV

Ural Federal University, Yekaterinburg, Russia

ANATOLY STEPANOV

Ural Federal University, Yekaterinburg, Russia

\section{Logistics infrastructure of the Eurasian Economic Union (EAEU) in providing transit from China to the European Union}

\begin{abstract}
Changes in the transport infrastructure in China, Asia and the Russian Federation go along with the main regional geo-economic trends of their development. The core of the suggested initiatives from China is the inclusion of Asian countries and Russia in the list of transit states in order to form alternative multimodal transport corridors in the direction «East-West» (China-EAEU-EU route). The present research deals with the problems of the development of logistics infrastructure in the Eurasian Economic Union (EAEU) with the purpose of further improvement of transit opportunities in the delivery of goods from China to the European Union. The authors of the article take into consideration that the EAEU logistics infrastructure is an established and evolvable system which is formed under the influence of globalisation processes and regionalisation of the world economy. The unified transport system of the EAEU countries formed during the Soviet period needs modernisation. Modern conditions of transportation routes in EAEU are observed on the basis of the specific examples as well as the transformation and modernisation options of a transport vector in the direction of China-EAEU-EU. The main trends in the infrastructure development in Central Asia are reflected in the regional projects of railway and automobile communications with the integrational priorities. The development of logistics infrastructure is essential for the full realisation of the transit potential inherent in the integration within the Eurasian region.
\end{abstract}

Keywords: China; EU; Eurasian Economic Union; integration; logistics infrastructure

Received: 30 December 2019

Accepted: 25 May 2020

\section{Suggested citation:}

Burnasov, A., Ilyushkina, M., Kovalev, Y., Stepanov, A. (2020). Logistics infrastructure of the Eurasian Economic Union (EAEU) in providing transit from China to the European Union. Prace Komisji Geografii Przemysłu Polskiego Towarzystwa Geograficznego [Studies of the Industrial Geography Commission of the Polish Geographical Society], 34(4), 138-150. doi: 10.24917/20801653.344.9

\section{INTRODUCTION}

The region of Central Asia and Russia is currently transforming from a peripheral transit space into a region that occupies key positions in the geopolitical system of Eurasia. One of the most important factors contributing to the growing importance of the 
region and determining its new geopolitical role is the potential for transit of goods from China to the European Union (EU). The EU is the main importer of China's industrial products. The implementation of the geopolitical concepts of China, the EAEU and the EU stimulates the active development of logistics infrastructure and the search for solutions to reduce costs in international transportation of goods.

Several integration projects of major geopolitical players (the Silk Road Economic Belt, the Eurasian Economic Union - EAEU, the "One Belt One Road") are currently being implemented in Eurasia. The development of logistics infrastructure is essential for the full realisation of the transit potential inherent in the integration within the Eurasian region. Investments, trade regimes, routes for laying roads and pipelines become not only a subject, but also a tool for reducing costs and increasing the efficiency of international transport corridors of Eurasia.

International transport corridors play an important role in the integration of Eurasian economies into the world economy with two functions: firstly, they ensure the delivery of goods to foreign trade partners and, secondly, they bring income to the budget in the form of payments for transit transportation of goods of other countries through the territory of Eurasia. The basic advantage of increasing transit traffic through the territory of the EAEU is a significant reduction in the distance, and, therefore, the time of delivery of goods. Thus, the period of goods delivery by sea, for example, from Berlin to the Chinese port on the Yellow Sea coast is twenty days, while the railway through the EAEU space reduces this time almost by half. Due to the advantageous geographical location, the development of international transport corridors passing through the EAEU is of great importance, as it covers three important directions, promising from an economic point of view: Russia, Europe and the Baltic States; China, Japan and SouthEast Asia; the republics of Central Asia and Transcaucasia. There is also a significant increase in security threats and geopolitical confrontation between a number of powers on the alternative sea route from China to the EU now. At the same time, the market of railway container transportation from China to Europe through Eurasia in the current decade is growing at an explosive pace, partly owing to the subsidies from the PRC.

The involvement of Eurasian countries in the world economic relations results in several requirements: to rethink approaches to the analysis of problems and to search for the tools to improve the efficiency of the logistics infrastructure of container cargo transportation of the EAEU in ensuring transit from China to the European Union.

\section{MethodS AND DATA}

The modern development of the transit logistics infrastructure in the EAEU is characterised by the influence of the institutionalisation of the interests of international actors. The key trends leading to the institutionalisation of international cooperation in the EAEU include fierce competition for resources, conflicts in the sphere of resource use, the introduction of foreign capital and foreign transnational actors into national economies. Limited basic resources and increased competition for them lead to the changes not only in the economic rules of behaviour in international relations, but also in the competition at the level of projects aimed at the development of logistics infrastructure for transit from China to the EU.

The empirical database is filled with the statistical materials and reports of the Federal Customs Service of the Russian Federation, freight turnover indicators of the 
Russian and Chinese Railways, and analytics of the «Eurasian Studies». The theoretical and methodological basis of this study is neoliberal institutionalism, which considers the creation of international institutions as a possibility of cooperation between the states. One of the topical areas of research is the study of the problems of institutionalisation of the interests of actors in international relations. R. Keohane and J. Nye made a significant contribution to the development of various aspects of the institutionalisation of the interests of the actors of international relations within the framework of neoliberal institutionalism (Keohane, 1989; Nye, Welch, 2012). International cooperation, particularly in the transport sphere, is described in the context of institutionalisation of interests of international relations actors. It is based on the principles of strategic partnership and is aimed to identify the features of normative and structural regulatory system formation, which influence the formation of goals and interests of actors in international relations.

The theoretical basis of this study is formed by traditional and modern concepts of interstate cooperation based on a systematic approach to international relations. The systematic approach to international relations has been developed both in the Western (Albert, Cederman, 2010; Bertalanfy, 1968; Buzan, Little, 2000; Kaplan, 2008; Luhmann, 2007; Waltz, 1979; Watson, 1992; and others) and in the Russian science (Bogaturov, 2012; Denisov, Luzyanin, Lukin, 2016; Manykin, 2009; and others).

The implementation of logistics projects within the framework of the Chinese initiative "One Belt One Road" is studied by the authors of such Russian research centres as the Institute of the Far East of the Russian Academy of Sciences, Higher School of Economics, MGIMO University, the Institute of history and archaeology of FEB RAS, Far Eastern Federal University, Carnegie Moscow Centre, the Institute of world economy and international relations named after E. M. Primakov, St. Petersburg State University and others. Such foreign research centres, as Stockholm International Peace Research Institute, the British research centre "Chatham House", the European Council on Foreign Relations, the Mercator Institute for China Studies, the Centre for Eastern Studies named after M. Karp (OSW), The Carnegie Foundation, The George Washington University, George Hopkins University, Friedrich Ebert Stiftung and others also take part in the study of the situation in the EAEU.

J. Mackinder and K. Haushofer, who view the Trans-Siberian railway and the Silk Road as a mechanism of Eurasian identity, play a special role in the study (Hauskhofer, Makkinder, 1995; Ratcel, 2019).

The issues of foreign trade, transport complex, development of international transport corridors have been studied by many authors, including Arsenov (2007); Vinokurov, Dzhadraliyev, Shcherbanin (2009), Larin (2017), Podberezkina (2015), etc.

The attention of the researchers is drawn to the assessment of logistics projects implemented within the framework of integration projects between the major geopolitical players (the Silk Road Economic Belt, the Eurasian Economic Union, "One Belt One Road"). Each initiative has developed several approaches to the implementation of the transit potential inherent in the development of Eurasia as a single region that requires the development of logistics infrastructure.

The main areas of the research include the analysis of projects aimed at the development of logistics infrastructure within the framework of the "One Belt One Road" initiative. The Russian experts also pay attention to such issues as opportunities and risks of China's cooperation with the EAEU countries. The fact that China is promoting 
the idea of concluding a free trade agreement in the SCO space (which carries obvious risks for national producers of post-Soviet States) and demands exclusive conditions and rights in a number of transport projects from the EAEU countries is one of the most critical issues connected with the implementation of the "One Belt One Road" initiative.

Foreign experts are currently conducting a comprehensive study of "One Belt One Road". The study of China's foreign policy is gaining pace due to the increase in its role in international affairs and the intensification of cooperation with many states. The projects of investments in logistics infrastructure are commercial initiatives. The important factors that motivate China to develop the logistics infrastructure are the following: to develop the Western regions of the country in order to achieve social stability and equalisation of living standards with the more economically developed Eastern provinces. The "One Belt One Road" initiative is perceived as a project competing with the integration initiatives of other countries in the Eurasian space, primarily with the Eurasian Economic Union. The experts of foreign Chinese studies centres are sceptical about the integration between the EAEU and "One Belt One Road" both because of the competition between the two projects, and because the approaches of Russia and China to the integration differ in terms of the aims that are achieved with the help of each other.

Thus, the logistics infrastructure of the EAEU will be considered as an established and evolving system with its own specific features and directions of development, which will allow considering the transit features of Eurasia in the context of cooperation between different states with their own, systemically determined interests in the region.

\section{PRIORITIES FOR THE DEVELOPMENT}

OF LOGISTICS INFRASTRUCTURE OF THE EAEU COUNTRIES

ON THE NATIONAL, REGIONAL AND INTERNATIONAL LEVELS

The EAEU space, including Northern (Bridges, 1990) and Central Asia (Russia and Central Asia) is situated between Europe and China and represents one of the largest and longest transits between West and East, North and South. For thousands of years, one of the main tasks for political forces in this territory was to create conditions for logistics transit. In a broader sense, transit logistics refers to the creation of certain conditions in a particular territory for the functioning of logistics infrastructure, both at the subregional and international levels. Transit also implies a form of organisation of living space, focused on the intensive interaction of different cultures, religions and types of management, providing a permanent effect of mutual enrichment of the participants.

Geopolitical factors have significant influence on the global transport system. Transport can unite nations, countries and even civilisations, and, on the other hand, become an insurmountable obstacle to global socio-economic, political and cultural exchange. At the same time, the development of logistics infrastructure depends on the demand and prospects for the growth of supplies via transport routes. The opportunities for growth of Chinese-Russian trade, China - EEU and China - EEU - EU transit will be considered further.

Since 2014, China's share in Russia's foreign trade has been growing (Figure 1). In 2019 Russia and China agreed to increase trade from $\$ 120$ billion to $\$ 200$ billion by 2024. Until 2019, Russia's supplies to China were metal, oil, gas, and supplies from 
China to Russia were light industry products. By 2024, diversification will be clearly observed in the commodity structure of export of both countries. In 2019, Russia has begun to supply China with mineral fertilizers, agricultural goods, and China has started to export high-tech engineering products and service solutions, including financial services, to Russia. The infrastructure projects of China within the framework of the "One Belt One Road" initiative will be the objects of future investments. Significant funds are allocated for the implementation of the project, their volume is twice the annual GDP of Russia. It is planned to invest in construction, infrastructure, new manufactures and telecommunications along the route from Central and Central Asia to Europe.

$24.4 \%$ of the total funding of the Russian national projects is directed to the implementation of the project of the Trans-Siberian railway modernisation. Due to the investments in logistics infrastructure, the capacity should increase by one and a half times (up to 180 million tons) by 2024. The project will increase the capacity of railway lines from the West to the East of Russia (for example, containers from Vladivostok to the Western border of Russia are planned to be delivered in 7 days), provide stable access to the ports of Asia, get new opportunities in international trade and, most importantly, contribute to the development of huge resources of Eastern Siberia and the growth of economic potential of its regions (Dubrovskaya, 2019).

The signing of the agreement on trade and economic cooperation in 2018 was the next stage in the expansion of cooperation between the EAEU and China. The agreement, which came into force on October 25, 2019 is "non-preferential", i.e. it does not imply the creation of a free trade zone. Import duties will not be reduced either by China or by the EAEU. The agreement implies the creation of working groups with the participation of plenipotentiary representatives of China, the Eurasian Economic Commission (EEC) and the EAEU member states on various specific areas: non-tariff barriers, customs cooperation, intellectual property, e-commerce, phytosanitary and veterinary control, etc. The institutional basis of the new logistics infrastructure is created, according to which representatives of the relevant state bodies meet on a regular basis, and where specific problems and barriers in mutual trade between the parties can be discussed. The agreement enables countries and businesses to adapt to the new conditions of mutual trade liberalisation.

The EAEU countries and China are not ready to create a free trade zone yet. The aim of the EAEU countries is the development of domestic markets, where it is possible to raise domestic production and enter the markets of third countries. The parties to the agreement are ready for negotiations on certain commodity items, where the reduction of import duties on the Chinese market and the EAEU market is advisable. It is necessary to seek for specific areas and to open markets asymmetrically. For instance, there are trade areas where import from the Russian side would be appropriate and would not create too much competition for Chinese manufacturers (for example, Russian ice cream). On the other hand, the Eurasian market needs Chinese goods, which have no analogues in the EAEU (Figure 2).

The undisputed driver of growth will be supplies via international transport corridors from China to the EU (Figure 3). Currently, about 98\% of the volume of the EU and China mutual supplies are served by sea transport, $1.5-2 \%$ by air transport and $0.5-1 \%$ by railway. Approximately $80 \%$ of goods between the EU and China are transported in containers, about $90 \%$ of goods were imported into the EU from China (import), and 70-75\% exported from the EU to China (export) (Euroasian Development Bank, 2018). 
The growth of transit container traffic through the territory of the EAEU countries will depend on the development of trade between China and the EU.

Almost the entire volume of the EAEU exports to China is formed by bulk and liquid cargoes, and most of the imports from China are delivered in containers. The export traffic from the EAEU countries to China is characterised by a low proportion of container cargo, which is around $1.5-2 \%$. This is due to the absolute predominance of

Figure 1. Foreign trade of the Russian Federation with ten major partners $(2014,2019)$

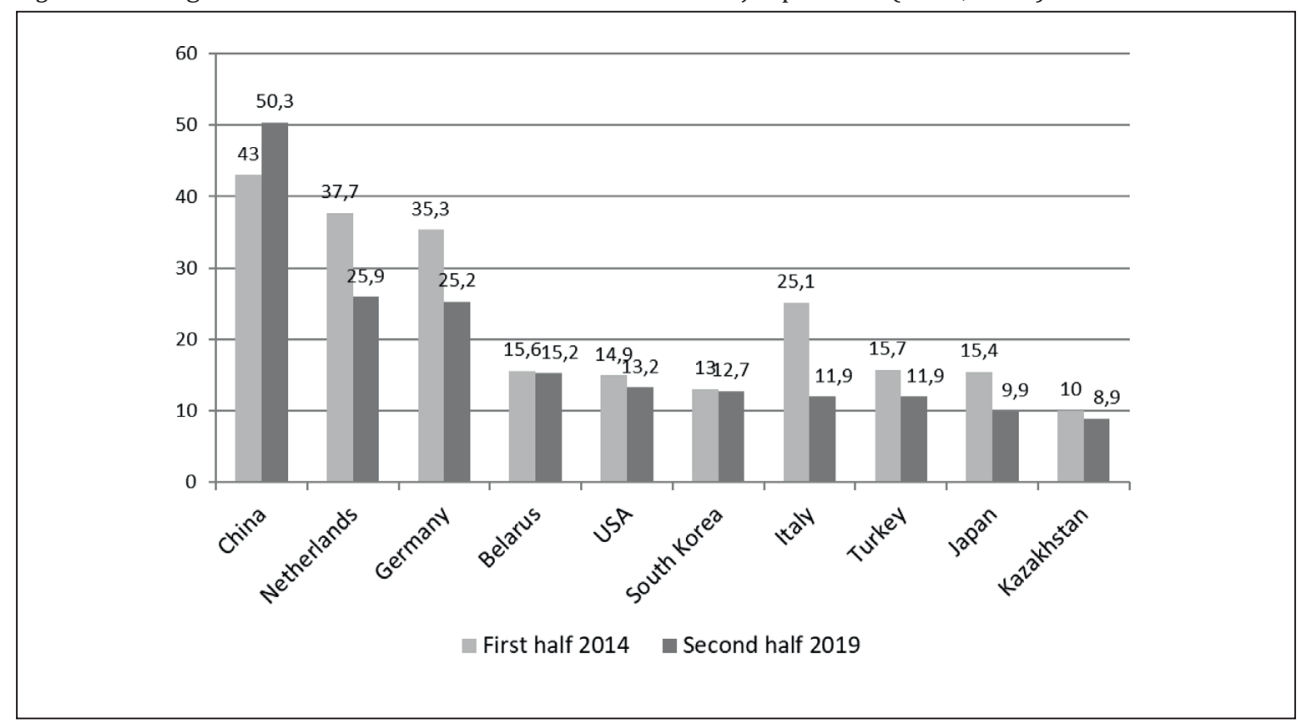

Source: FCS Russia

Figure 2. Trade of goods of the EAEU-China (2014-2018)

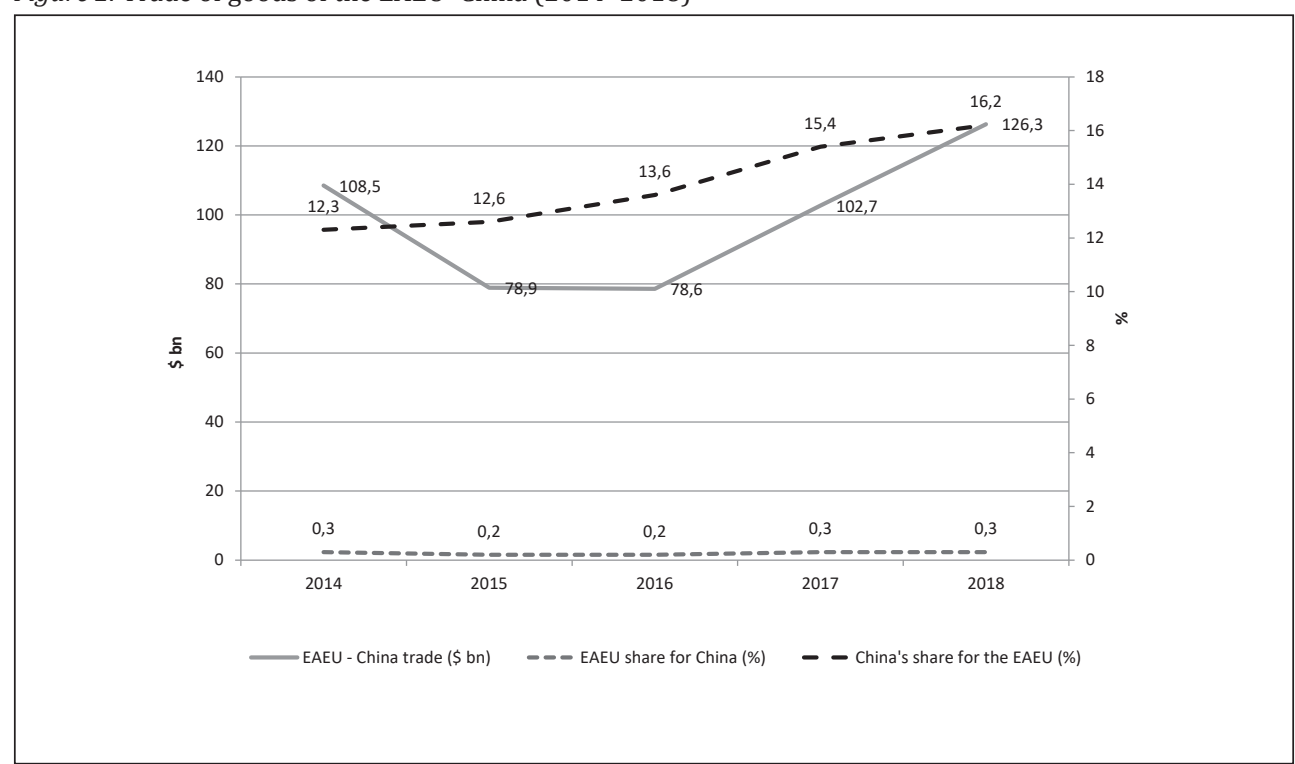

Source: ECE Department of statistics and http://eurasian-studies.org 
Figure 3. Number of container trains sent from China to Europe

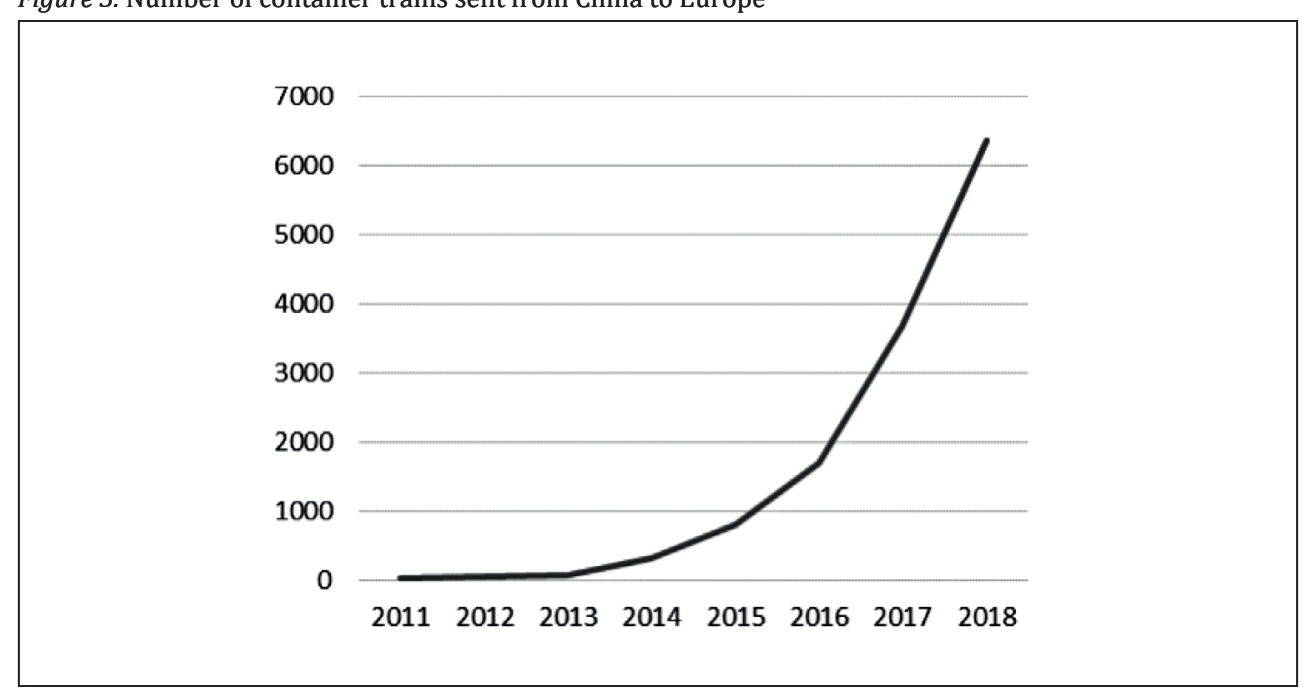

Source: http://www.china-railway.com.cn

"non-containerised" goods in its commodity structure (fuel, minerals, timber, fertilizers, agricultural raw materials). The share of container cargo in the structure of imports of the EAEU countries from China has grown significantly over the decade: from 35 to $55 \%$. The commodity structure of cargo flow from China with the dominance of container groups of goods stimulates further growth of its containerisation level.

Further growth of railway container turnover between the EU and China (with transit through the EAEU) is expected. To attract additional cargo traffic between the EU and China, the EAEU countries need to further develop transport infrastructure and remove barriers.

\section{DEVELOPMENT FACTORS OF THE EAEU LOGISTICS INFRASTRUCTURE IN ENSURING TRANSIT FROM CHINA TO THE EU}

International transit is the export of transport services provided by national companies to the cargo owner and carrier when following a foreign cargo or vehicle through the territory of a given country. The set of these services depends on the level of development of the national distribution network and its quality. First of all, it includes the services of national carriers, forwarders, and operators. In addition, transit is a catalyst for the development of a wide range of related services of refuelling vehicles, organising trade and feed supply, repairing vehicles and maintenance service (Arsenov, 2007).

It is worth noting that the positions of each side of the China - EAEU - EU in terms of security of supply will differ:

To ensure the security of supplies, the interests of importing countries, primarily EU countries, will be guaranteed long-term and stable supply of goods and services from external sources at a reasonably low cost of logistics. One of the key requirements is participation in infrastructure projects of the Chinese direct investors, instead of bank lending. 
The second group of countries is interested in demand security. The interests of exporting countries, especially China, in the longer term South Korea is interested in, are reduced to ensure stable financial revenues from the sale of goods and services at reasonably high prices. International practice shows that the interests of importing and exporting countries do not always coincide, primarily in terms of prices.

The third group of countries is interested in transit security and is directly related to the interests of transit countries (EAEU and Eastern Europe). The requirements are for these countries to receive the maximum profit for the provision of transit services for the transportation of goods and services through their territory. Investment in alternative routes for East-West container trains (including border crossings).

The situation with the pass-through capacity and carrying capacity of internal railway networks along the China - EAEU - EU axis is as follows: China's infrastructure of dynamically developing Chinese Railways fully provides potential volumes of container traffic along the China - EAEU - EU axis. High-speed traffic in the Western direction is organized to the city of Urumqi. As part of the project to develop the Central Eurasian corridor, it is also planned to launch high speed cargo transit on the Urumqi-Dostyk district by 2026.

In the main Russian directions of the East-West transportation corridor passing through the territory of Russia, the railway lines are double-track. Modernisation of branches from the TRANS-Siberian railway to the state border with China and Mongolia to Zabaikalsk and Naushki continues. Russian Railways is completing the implementation of electrification projects of these districts, as well as carrying out a comprehensive reconstruction of the Zabaikalsk station; the Current state of the railway infrastructure of Kazakhstan in the directions of international transit is characterised by the lack of sufficient reserves of pass-through capacity. The development of future transit container freight traffic will require serious modernisation: the development of areas under common network standards, including the weight and length of freight trains; the construction of second main tracks on the limiting districts; the construction of bypasses of major transportation hubs (for example, the Almaty railway junction); electrification of sections on the approaches to international border crossings with China.

Container transit through Belarus is carried out mainly on the Osinovka-Orsha-Brest district, which is double-track and electrified. A fibre-optic cable has been laid along the entire length of the transportation corridor on the territory of the Republic of Belarus. In the future, by 2020, it is planned to modernise the signals and interlocking and communication devices for the organisation of high-speed traffic. In 2011-2017, about $\$ 2.5$ billion was invested in increasing the potential of the Belarusian railway, of which $\$ 700$ million was invested in the development of Silk Road routes. In particular, 30 modern electric locomotives were purchased, much attention was paid to the electrification of the main transport corridors (Ananyev, 2017). The pass-through capacity and carrying capacity of the railway infrastructure of the EU countries are limited and will not be able in the medium term to carry out unhampered transit of the growing container traffic. This is largely due to the differences in the technological and regulatory aspects of the rail transport used in China, the EAEU and the EU (this will be discussed below).

Major projects are not required to increase the capacity of land transport corridors along the China - EAEU - EU axis and increase their competitiveness compared to sea routes. It is required to dot the "bottlenecks" of the transport infrastructure. The 
main factors hindering the growth of container flows between China and EU countries are unbalanced container flow from China to the EU and back, insufficient capacity of border crossings at the EAEU-EU border. In 2017, the processing capacity of the Brest - Malashevichi crossing was almost fully operational.

The degree of loading by container transportation of the railway infrastructure of the EAEU countries along the China - EAEU - EU axis (its pass-through capacity and carrying capacity) is still small and does not have a restraining effect on their volumes and intensity. However, there are no sufficient pass-through capacity reserves for the future until 2020 and in the long term. Nevertheless, on the basis of the implementation of existing projects for the development of the busiest sections of the Russian Railways, Kazakhstan Railways and Belarus Railways networks along the China - EAEU - EU axis, the pass-through capacity and carrying capacity of the network infrastructure will fully ensure the projected volumes of international container transit.

The most important area of investment is already the creation of support transport hubs in Russia, Kazakhstan and Belarus. The lack of supporting transport and logistics centres on the territory of the EAEU increases the total mileage of transport and, accordingly, the transport costs of shippers, as well as increases the time of accumulation and distribution of goods. The priority objectives of the creation of transport hubs in the EAEU countries should be the processing of container cargo (from China and the $\mathrm{EU})$ on the border territories of the EAEU and their further distribution by rail or road transport; the accumulation of container cargo on the territory of the hubs and their further export by rail or road transport to China and the EU countries; in the future, it is possible to accumulate container cargo on the territory of the hubs for further reloading of transit container trains moving along the China - EAEU - EU axis.

Development plans of transport and logistics centres in the EAEU countries (for instance, the Concept of creating terminal and logistics centres on the territory of the Russian Federation, Russian Railways, the Master plan for the development of the transport and logistics system of the Republic of Kazakhstan, Kazakhstan Railways) will also have a stimulating impact on the development of container flows.

A promising direction for the development of international cargo transportation is the use of special containers for chemical and mineral cargoes, refrigerated containers for the transportation of food products. This niche in the EAEU space has not yet been fully developed by business. Nevertheless, the production of such products has high prospects, including investment activities.

An important condition for barrier elimination in the field of international freight transport is the information exchange between the countries on the territory of which the main routes of container transport pass, about long-term (5-10 years) projected growth of mutual rail transport: promising directions and volumes of cargo transportation; plans for the average daily volumes of acceptance/delivery of cars at the junction points of gauge change, etc. The exchange of information will allow for determining in advance the need for organisational and technical measures as well as measures for the development of railway and related infrastructure for the unhampered movement of goods within the prescribed time limits.

It is necessary to raise to full unification the administrative and legal aspects concerning the movement of container trains on the China - EAEU - EU axis. The progress achieved in solving the problems with delays at the borders associated with border and customs inspection operations and traceability records (taking into account the entry 
into force of the new EAEU customs code on January 1, 2018 and registration of all transcontinental container transport by the CIM/SMGS consignment note from May 1, 2017), brings to the almost complete elimination of administrative and legal barriers at the EAEU - China border and within the EAEU that affect the realisation of the potential of cargo flows. All relevant operations from 2018 can be carried out during the change of track gauge and will not take additional time.

To implement the digital transformation of the logistics infrastructure, it will be necessary to create a management and coordination system, the key elements of which can include monitoring key performance indicators of the transport complex; formation of a geoinformation model of the transport complex; collection of information on traffic flows on the main highways, in transport hubs, at the points of origin of flows; maintaining a transport database; maintaining a statistical database and monitoring transport; development of management decisions.

Thus, key factors influencing the development of logistics infrastructure include, in short term, the growth of supplies between the EU and China via the EAEU Railways; long-term supply growth is constrained by the need to modernise the physical railway infrastructure in the EAEU, the need for a lower tariff, as well as guarantees of preservation of subsidies from China; lack of capacity of checkpoints on the EAEU-EU border; differences in the length of container trains in China - EAEU - EU; unification of accompanying documents and technical regulations is needed (inconsistency of the terms of the Convention concerning International Carriage by Rail (COTIF) and the Agreement on International Goods Traffic (AIGT).

\section{CONCLUSIONS}

In conclusion, the development of the EAEU logistics infrastructure is one of the important areas of research in economic geography. The unified transport system of the EAEU countries formed during the Soviet period needs modernisation. The formation of a single market encourages countries to attract foreign investment in logistics infrastructure. The main directions of modernisation of the logistics infrastructure are point modernisation of the transport infrastructure of supplies from China to the EU through the EAEU; transition from investments in transit to the creation of cargo processing centres; the use of digital logistics in the management of sustainable development of logistics infrastructure; the development of international cargo transportation through the use of special containers for chemical and mineral cargoes, refrigerated containers for transportation of food products. The creation of an efficient and technologically updated logistics infrastructure will contribute to the accelerated transportation of goods and the successful implementation of the transit potential of the EAEU countries.

The main growth potential of container traffic in the direction of China - EAEU EU is accounted for by China's trade with EU countries, part of which can be switched from sea transport to railway. In short term, the objective opportunities for the development of container traffic between the EAEU and the EU, as well as between the EAEU and China, are significantly smaller due to the limited volumes of goods using a container as a tare.

The effectiveness of infrastructure projects depends on many factors: financial conditions, the growth of national welfare and the density of real international economic ties. One of the main factors in the development of logistics infrastructure projects 
in the space was the transformation process of national economies. Protectionism often increases during the crisis, which can have some restraining effect on economic integration and infrastructure projects. But, at the same time, the need to cope with common challenges makes the crisis a constructive incentive for integration projects. Regional organisations are involved in the task of strengthening integration effects. The growing intensity of trade and economic relations between the member countries of the regional organisation requires ensuring the functioning of markets, improving transport infrastructure, and promoting the implementation of joint projects.

An important condition for sustainable long-term economic development in the EAEU space is the construction of trade and economic ties on the basis of effective cooperation projects that can work even in the presence of customs barriers and protective measures. Such projects should be characterised by global competitiveness (otherwise, intensive interaction of economies means only the preservation of existing production chains or the growth of unregulated forms of trade). Most importantly, it is necessary to assess any projects and models of cooperation in terms of whether they contribute to the socio-economic development of countries, whether they are friendly to human security and the environment, and whether they develop positive integration scenarios.

\section{References}

Agreement on economic and trade cooperation between the Eurasian Economic Union and its member States, of the one part, and the People's Republic of China, of the other part. (2018). Retrieved from: http://www.eurasiancommission.org/ru/act/trade/dotp/sogl_torg/ Documents/Forms/AllItems.aspx.

Albert, M., Cederman, L.-E. (2010). System Theorizing in IR. In: M. Albert, L.-E. Cederman, A. Wendt (eds.), New Systems Theories of World Politics. Basingstoke, England; New York: Palgrave MacMillan, 3-22.

Ananyev, R. (2017, October 7). Perspektivy rosta [Growth Prospects]. Zheleznodorozhnik Belorussii [Belarusian Railway]. Retrieved from: http://xpress.by/2017/10/07/perspektivy-rosta-2/ [in Russian].

Arsenov, V.I. (2007). Prospects of integration of Russian transport into the system of Eurasian transport links. Transport Rossijskoj Federacii [Transport of the Russian Federation], 10, 4-7.

Bertalanfy, L. (1968). General System Theory. Foundations, Development, Applications. New York: George Braziller.

Beifert, A., Shcherbanin, Y., Vinokurov, E. (2018). Trans-Eurasian Land Transport Corridors: Assessment of Prospects and Barriers. Laxenburg, Austria: International Institute for Applied Systems Analysis.

Bogaturov, A.D. (2012). Modern international order. In: International process, 1, 66-89.

Bridges, E.M. (1990). Northern Asia. In: World Geomorphology. Cambridge: Cambridge University Press, 124-126.

Buzan, B., Little, R. (2000). International Systems in World History. Remaking the Study of International Relations. Oxford; New York: Oxford University Press.

Denisov, I.E., Luzyanin, S.G., Lukin, A.V. (2016). Chinese global project for Eurasia. Moscow: Scientific Expert [in Russian].

Dubrovskaya, V. (2019). New backbone of the Russian economy Expert, 8, 18-24.

Euroasian Development Bank. (2018). Silk Road Transport Corridors. Assessment of Trans-EAEU Freight Traffic Growth Potential. Saint Petersburg: Centre for Integration Studies, report 49. Retrieved from: https://eabr.org/upload/iblock/0a8/EDB-Centre_2018_Report-49_ Transport-Corridors_ENG.pdf.

Hauskhofer, K., Ratcel, F. (2019). Teoriya "zhiznennogo prostranstva" [The theory of "living spaces]. Moscow: Algoritm [in Russian].

Kaplan, M. (2008). System and Process in International Politics. ECPR Press. 
Keohane, R. (1989). International Institutions And State Power. Essays in International Relations Theory. Boulder, San Francisco; London: Westview Press.

Kofner, Yu.Yu. (2018). Common market of the EU-EAEU: prospects of convergence of technical regulation systems. Modern Eurasian Studies, 1, 7-14.

Larin, O.N. (2017). Prospects for the Integration of Transport Systems of the Eurasian Economic Union. Problemy nacional'noj strategii, 4, 152-170.

Luhmann, N. (2013). Introduction to Systems Theory. Cambridge: Polity Press.

Makkinder, H.J. (1995). Geograficheskaya os' istorii. Polis. Politicheskie issledovaniya, 4, 162-169 [in Russian].

Manykin, A.S. (2009). Consistency in international relations: Content, causes of formation and stages of development. In: A.S. Manykin, N.A. Kosolapov, N.N. Naumova (eds.), Fundamentals of the General Theory of International Relations. Moscow: Moscow State University, 39-77.

Nye, J., Welch, D.A. (2012). Understanding Global Conflict and Cooperation. An Introduction to Theory and History. Boston, MA: Pearson.

Podberezkina, O.A. (2015). Transport Corridors in the Russian Integration Projects, the Case of the Eurasian Economic Union. MGIMO Review of International Relations, 1, 57-65.

Top, Yu. (2008). A single transport space of the EurAsEC. Loginfo, 9, 6-10.

Vinokurov, E., Dzhadraliev, M., Shcherbanin, Y. (2009). International transport corridors of EurAsEC. Faster, Cheaper, More. A Sectoral Overview, Almaty: Eurasian Development Bank, 2009 [in Russian].

Vinokurov, E.Yu., Lobyrev, V.G., Tikhomirov, A.A., Tsukarev, T.V. (2018). Transportnye koridory Shelkovogo puti. Aanaliz barerov i rekomendacii po napravleniju investicij [Transport corridors of the silk road. Analysis of barriers and recommendations for investment direction]. Petersburg: Euroasian Development Bank [in Russian].

Vision and Actions on Jointly Building Silk Road Economic Belt and 21st-Century Maritime Silk Road. (2015). Retrieved from: https://reconasia-production.s3.amazonaws.com/media/ filer_public/e0/22/e0228017-7463-46fc-9094-0465a6f1ca23/vision_and_actions_on_jointly_building_silk_road_economic_belt_and_21st-century_maritime_silk_road.pdf

Waltz, K. (1979). Theory of International Politics. Reading, Mass.: Addison-Wesley.

Watson, A. (1992). The Evolution of International Society. A Comparative Historical Analysis. London; New York: Routledge.

Alexander Burnasov, PhD, Deputy Head of the Department of Theory and History of International Relations, associate professor, Chair of International Relations, Ural Federal University named after the first President of Russia B.N. Yeltsin, Yekaterinburg, Russia. Research interests: development of transport logistics in the context of globalisation, international communication and international cooperation, history, economy, logistics, globalisation. Author of over 30 works in this field, including 3 monographs.

ORCID: https://orcid.org/ 0000-0002-9568-4542

\section{Address:}

Ural Federal University

Department of Theory and History of International Relations

St. Lenin 51, office 386, 620083 Yekaterinburg, Russia

e-mail: burnasov@mail.ru

Ilyushkina Maria, associate professor, Chair of Linguistics and Professional Communication in Foreign Languages, Ural Federal University named after the first President of Russia B.N. Yeltsin, Yekaterinburg, Russia. Research interests: cross-cultural communication, linguistics, world economy and clusters. Author of over 30 works in this field, including 2 monographs.

ORCID: https://orcid.org/ 0000-0003-4612-3025

\section{Address:}

Ural Federal University

Department of Theory and History of International Relations

St. Lenin 51, office 386, 620083 Yekaterinburg, Russia

e-mail: ilyushkina_maria@mail.ru 
Yury Kovalev, PhD in Geography, associate professor, Chair of International Relations, Ural Federal University named after the first President of Russia B.N. Yeltsin, Yekaterinburg, Russia. Research interests: innovative regions of the world, processes of convergence and divergence in the world economy, problems of modern economic geography, economic geography, world civilizations. Author of over 40 works in this field, including 5 monographs.

ORCID: https://orcid.org/0000-0002-2272-104X

\section{Address:}

Ural Federal University

Department of Theory and History of International Relations

St. Lenin 51, office 386, 620083 Yekaterinburg, Russia

e-mail: yykowaljow@gmail.com

Anatoly Stepanov, PhD in Geography, professor, Head of the Chair of Economics of Institute of Further Education and Vocational Training, Ural Federal University named after the first President of Russia B.N. Yeltsin, Ekaterinburg, Russia. Research interests: socio-economic asymmetry in the economic development of the regions, the impact of globalisation on the transformation of regions, theory of clusters and cluster strategies, world economy, globalisation, cluster policy, economic geography. Author of over 360 works in this field, including 6 monographs.

\section{ORCID: https://orcid.org/0000-0002-6501-1072}

\section{Address:}

Ural Federal University

Institute of Further Education and Vocational Training

St. Turgenev 4, office 350, 620083 Yekaterinburg, Russia

e-mail: anatoly_stepanow@mail.ru 